\title{
Managing Egyptian Five-Star Hotels during Times of Crises
}

\author{
Noha Saad EL Shaer
}

Faculty of Tourism and Hotel Management, October 6th University, Egypt

\section{Abstract}

Purpose- The hospitality industry is facing different types of crises resulting from both naturally occurring disasters, and man-made ones such as earthquakes and terrorism. In the case of the Egyptian hotel operations, Crises present extraordinary conditions needing more than working to decrease the negative effects of crises through prompt decisions, but also further efforts including pre-crises as well as post-crises planning to minimize non-desired influences and maximize the benefits of the situation. Crisis management strategies are developed and implemented to make sure that the hotel operation survives the process of crisis. The hotel operation may need a thorough rehabilitation after recovery from a crisis. So that, the study will concentrate on the strategies of crises management through three axes each one of them represents one stage of the strategic approach of crises management.

The strategic approach of crisis management includes three steps that start with the pre-crisis stage to develop a plan for potential crises. The second step will be the implementation of the prepared plans and scenarios during the crisis, and the last one will be for the rehabilitation and restructuring after recovery of the crisis without decreasing or minimizing in hotel's quality standardization.

Design/methodology/approach-Questionnaires for the top management and staff will be used in this research in order to gain the desired data about the strategic crisis management process. The collected data will be statistically analyzed by using different measures including descriptive ones, such as frequencies, Mean, and standard deviation as well as cross tab.

Research limitations/implications - the researcher preferred to focus on the most successful modern strategies in the face of crises agreed by the researcher.

It can be applied to the current study community, which is as follows:

- (changing path strategy)

- (crises fragmentation strategy)

- (containment crisis strategy)

- (exhausting crisis strategy)

- (reserve mobilization strategy)

The questionnaire was designed to capture information about the research to meet the needed objectives. Respondents were asked to indicate their level of agreement with each question on four choice Likert-scale metric.

Keywords: Crisis Management, Egyptian Hotels, Hotel Crisis Plan, Hotels' Services and Product.

\section{Results and Recommendations}

- Most of the Egyptian hospitality adopts a defensive crisis management strategy

- The crisis management practices in the Egyptian hospitality are immature and require major strategic planning actions from both the governmental tourist organizations and private hospitality.

- The governmental authority should provide technical support for the hospitality in the context of crisis management

- They need to integrate crisis management within the strategic planning for the enterprise. 


\section{Introduction}

Nowadays, the world faces an unprecedented situation in terms of the continuous challenges and rapid changes that lead to the existence of different types from the crises and their impacts on the results of the economic and financial Business organizations and their ability to survive and adapt to the environment in which it operates. the success of organizations depends mostly on their ability to keep pace with developments which it requires adaptation to speedy environmental changes and to monitoring each the environmental changes which occur and often are complex that help them adapt to this environment. The issue of crisis management becomes very important matter when we know that it is necessary. (Al Khashaly, Al Kotb, 2007).

In order to the organization's capacity to deal with the crises which pass through amidst these volatile environmental conditions, it must have clear strategies to help it successfully to manage the various crises (Septi 2002). Crisis Management represents the methodology through which the crisis is dealt with in light of the knowledge, awareness, available capabilities, skills and prevailing management patterns (Al-Sirafi 2008).

Crises give painful lessons for managers and therefore, they have placed on the daily management agenda. Previous fire-fighting practices solutions should be replaced by relying on emergency solutions when the crisis looms in the horizon through reconsideration at the current direction of the organization by thinking and strategic planning for crisis management. (Spence, 1999; Collison and Parcell, 2001; Ford and Angermeier, 2004; Kim, 1998).

According to Henderson (2006), it is crucial that managers in the tourism industry provide the highest level of knowledge of crisis management strategies, decision-making skills and the necessary expertise for dealing with crisis conditions. Egyptian tourism foundations have been strongly influenced during the past years as a result of economic and political instability. They have been struggling to keep their business in this unfavourable environment, adopting different strategies for crisis management.

However, Although the fact that the tourism crisis attracts the attention of many researchers with different perspectives including types, causes, effects and the knowledge of management, the references about crisis management strategies in tourism are extremely rare and needs more academics for research about it (Faulker 2001; Ritchie, 2004; Laws and Prideaux, 2007; and Scott and Laws, 2005; Pforr, 2006).

In spite of the importance of the tourism sector in general in Egypt and the hotels sector in particular, it is living in a complex environment because of the speedy economic and social changes that Egypt has undergone, according to that, there was the need for strategies to manage these crises in order to fit the requirements of the internal and external environment of the Egyptian hotels works (Valackiene, 2010).

Managing costs effectively during any crisis is probably the key to being able to remain in business during and after crisis, as any reduction in hotel occupancy rates will translate into a drop in the revenues. However, this cost saving exercise should be conducted in a way that allows the hotel to bounce back quickly once the demand for their services returns. Moreover, a significant drop in demand and revenues due to a crisis will also require cutting costs in any area possible. For example, the supply costs for power and/or electricity can be managed by closing areas of the property; e.g. by closing a floor and concentrating the guests accommodation in dedicated areas will save power and allow for better utilization of staff (Niininen, 2013). 


\section{Research problem}

The research problem emerged from the exposure of the hotels sector in Egypt to strong competition and many external and internal pressures economic and political led to putting of the hotels sector in many crises, which necessitated the identification of the reality of the use of strategies to deal with these crises in order to maintain the level of performance and enhance the competition locally and internationally particularly in light of the country's economic and political crisis for treatment what this sector suffers from weak points, failure positions and financial, administrative and marketing and challenges as a result of those crises.

Accordingly, the purpose of this research is to identify the reality of the use of crisis management strategies in the management of operations of the Egyptian five-star hotels during times of crises in the city of the Greater Cairo.

The problem can be made clearer by answering the basic question:

1- What are the most important crisis management strategies used (change of course, tactical reserve, emptying of the crisis, breaking up of the crisis, containment of the crisis) in the management of Egyptian hotels works during times of crisis?

This question is divided into the two following sub-questions:

1. What is the reality of the use of crises management strategies in the management of Egyptian hotel works during times of crisis?

2 - What is the most important crisis management strategy in the management of Egyptian hotel works during times of crisis?

\section{The hypotheses of the study}

According to the problem of the study, the following main hypothesis has been formulated, which results from several hypotheses and it will be tested, therefore, the hypothesis of the study starts in the attempt to answer the questions that were mentioned in the problem of the study and was in line with the theoretical propositions and explanations for the behaviour of the variables of the model of the study. The management of the Egyptian hotels does not depend on crisis management strategies during the crisis time. The following sub-assumptions are derived from this hypothesis:

$\mathrm{H}_{01}$ : The management of the Egyptian hotels does not rely on a strategy to change course during the crisis time.

$\mathrm{H}_{02}$ : The management of the Egyptian hotels does not rely on a tactical reserve strategy during the crisis time.

$\mathrm{H}_{03}$ : The management of the Egyptian hotels does not rely on the strategy of emptying the crisis during the crisis time.

$\mathrm{H}_{04}$ : The management of the Egyptian hotels does not rely on a strategy of the breaking up of the crisis during the crisis time.

$\mathrm{H}_{05}$ : The management of the Egyptian hotels does not base on a strategy of the containment of the crisis during the crisis time.

Also Horváth et al, (2014), referred to three actions that should be taken in crisis time:

First: Decrease of advertising spending

Reduced advertising and media spending may be compensated by better targeted ads, which reach the real, interested targets that therefore increase advertising effectiveness.

Second: Promotional actions to increase demand

Decreasing consumption is the most obvious consumer reaction in critical times; therefore companies often use sales promotion actions to keep price sensitive customers. 
Third: Use of alternative media

The pressure to spend less on advertising made companies to find new alternative ways, new media to compensate for the lower general spending. New media is not necessarily online; it is more part of the 360 degree marketing.

\section{Objectives of the study}

1. To identify the reality of the adoption of the management of Egyptian hotels on crisis management strategies during the crisis period.

2. Defining the crisis management strategy (changing the course, the tactical reserve, emptying the crisis, breaking up the crisis and containment the crisis) where the management of the most important Egyptian hotels depends on and what the level of its enforcement is.

3. Provide the necessary recommendations for crises management in the management of Egyptian hotels.

\section{The importance of research}

The importance of this study is that the concept of the crisis has become one of the widespread concepts in our contemporary societies, but it has become more complex in its enforcement on the tourism sector in general and the hotel sector in particular where the economic and policy crises that the sector of the Egyptian hotels is undergoing, requires the need to the permanent readiness for address to it due to the importance of ensuring the sector of Egyptian hotels.

The importance of this research is that it deals with the Egyptian hotel sector, which is considered to be a strong economic vector in the Egyptian tourism sector and thus the Egyptian economy, which has been exposed to many crises due to the various and multiple fluctuations that may affect it.

\section{The applied importance}

The practical importance of this study stems from what is expected to be provided by information that can serve the pharmaceutical companies in Jordan, which can be summarized as follows:

1 - Provide recommendations to decision-makers as regarding the knowledge of the reality of different crisis management strategies in the management of operations of the Egyptian hotels during times of crisis.

2 - Identify the most crisis management strategies in the management of operations of the Egyptian hotels during periods of crisis.

\section{Theoretical importance}

1- Providing a scientific analytical material serving the management of the operations of the Egyptian hotels in the greater Cairo. The society of the study through the statement of the reality of using crises management strategies in the management of operations of the Egyptian hotels during times of crisis so that these managements can use an appropriate strategy in the face of various crises.

2. Making a contribution in the field of the scientific studies related to the management of operations of the Egyptian hotels in the greater Cairo. 


\section{Review of Literature \\ Procedural definitions \\ Crisis}

It is a sudden and uncontrollable event that it threatens the life of the organization and, in some cases, the life of persons, results in positive or negative effects depending on how it is dealt with. This definition has been agreed upon by: (Abu-Fara, 2009), Coombs (1961), (Thelwall and Suart, 2007)

The process of the strategic planning of crises through practical tools during the various stages of the crisis to address and trying to control them to avoid its negatives and take advantage of its positives. This definition was agreed upon by: (Sabti, 2002) (Maher, 2006) (Fenrn-Bansk, 2007) The term of the crisis has become one of the common terminology at all levels and at various levels of society. Crisis management is one of the main areas of interest in management, where it requires a special kind of managers who have many skills including courage, stability, balance of mind, creativity, (Ahmed, 2002). The crises that occur in the organizations are only sudden changes to the internal or external environment of the organization without the expectation or opportunities to avoid them, and here it can be said that failure to deal with the crisis rationally or its well management, is the particular tendency to move from bad to worse (Tirawi, 2008). Therefore, there is a need for appropriate strategies to deal with them because of their impact on the performance of the work of the organizations (Human Resources Development Institute, 2011).

\section{Crises management}

The crisis management is one of the developing topics that still needs further theoretical development. Researchers differed on the definition of the crisis. (Carthage, 2007) There are many researchers who have published many books on crisis management, but there is no unified concept between those the researchers (Coombs, 2007). One of these reasons is due to the different views of researchers and the types of research they do.

The crisis as: a basic event such as fires, floods, or other disasters, result in losses in the Company's physical assets and influence the organization's ability to achieve the profits, Also, there is another definition of crisis which means an unexpected event and suddenly threatens the organization's operations and lead to the organization's reputation and financial position disorder (Coombs, 2007).

Both of (Mitroff and Anagnos 2001) define the crisis as an event that affects or has the potential to affect the organization as a whole. If something affects a separate part of the organization, it cannot be considered a major crisis, whereas if it is difficult to contain it across the parts of the organations that considers a major crisis.

There are many concepts that define crisis management, including Goel and Suresh 2009, as a system that is used to avoid emergencies and how to deal with them when they occur, in order to mitigate their destructive effects. Larson \& Rudwall 2010, are defined Crisis as a set of functions or processes of identification to study and predict the subject of the crisis. It is also known as the process by which warning signals are defined in order to reduce a potential crisis (Yamamoto \& Sekeroglu, 2011)

Al-Sirafi (2003) defined it as a methodology for dealing with the crisis from planning, implementing, monitoring and feeding in the light of preparations, knowledge, awareness, perception, available capabilities, skills and prevailing management patterns. In another definition it is a purposeful activity that is based on research and obtaining the necessary information, (Ahmed, 2002) The aim of crisis management is to provide time-bound decisions 
based on the best facts and to ensure that the crisis is resolved. (Pearson \& Christine, 2002). (2006) believes that crisis management is a science that examines the possibility of identifying risks and what to do and strategies for preventing or mitigating their effects to a more acceptable level.

The crisis management is based on fabricating crises and finding them as a means of covering up and camouflaging the existing problems facing the administrative entity, forgetting a problem, only when there is a problem that is bigger and more influential to overwhelm the existing problem. Thus, the exhausted administrative entity is exposed to crisis after crisis, It has successive crises until it is completely destroyed (Abu Fara 2009)

Through previous concepts of crisis management, the elements can be identified as follows:

- A special administrative process consisting of a series of exceptional measures that go beyond the usual job description of administrative tasks.

- The crisis is managed by a set of efficient and specially trained management capacities in the face of crises

- Crisis management aims to minimize losses

The researcher has identified the crisis - and according to the above - it is as an unusual situation that goes beyond control and leads to the interruption of the labour movement or falling to an unusual degree, so that it threatens to achieve the goals required by the organization and on time.

\section{The reasons of crisis}

Tourism is particularly prone to external threats, which by their nature are unpredictable and need to be addressed through effective crisis management processes. A tourism crisis can be described as a crucial or decisive point or situation; a turning point; an unstable condition (political, social or economic affairs), whereas a disaster can be described as an occurrence causing widespread destruction and distress; (Rousaki and Alcott, 2007).

There are many factors that cause the crisis and it can be identified a large extent, and in general it can be said that the crisis is the result of non-interconnectedness between the organization and its internal and external environment (Yamamoto and Sekeroglu, 2011).

Table 1: Reasons of the Crisis

\begin{tabular}{|c|c|c|c|c|}
\hline No. & Author & Year & Page & \multirow{5}{*}{$\begin{array}{l}\text { Reasons } \\
\text { 1- The weakness of material resources } \\
\text { The objectives of the organization are unclear } \\
\text { 3- Weak decision-making system } \\
\text { 4- Poor relations between employees } \\
\text { 5- Lack of interest in training }\end{array}$} \\
\hline \multirow{4}{*}{1} & Abu Fara & 2009 & $89-91$ & \\
\hline & Jad Allah & 2008 & 18 & \\
\hline & Sirafi & 2003 & $24-27$ & \\
\hline & Maher & 2006 & 328 & \\
\hline 2 & $\begin{array}{c}\text { Lareson \& } \\
\text { Rudwall }\end{array}$ & 2010 & 6 & $\begin{array}{l}\text { 1. Economic reasons: crises related to employment and } \\
\text { markets } \\
\text { 2. Reasons related to information: loss of stored } \\
\text { information, valuable to suppliers and consumers } \\
\text { 3. Material causes: Product failure and loss of raw } \\
\text { materials } \\
\text { 4. Reasons for human resources: high incidence and } \\
\text { workplace violence } \\
\text { 5. Political reasons: military coups and revolutions } \\
\text { 6. Natural causes: volcanoes, earthquakes, floods and } \\
\text { hurricanes }\end{array}$ \\
\hline
\end{tabular}


The researcher finds that the causes of crises are multiple, and renewed with the renewal of ways of life. The investigator researcher, the successful administrative and the expert have to reveal these reasons and identify aspects and dimensions and diagnosed well enough to be able to deal with and manage the crisis successfully.

\section{Characteristics of the crisis}

Fishman \& Donald 1999 mentioned the main characteristics of the crisis as follows:

- The crisis may be a sudden event or an expected event.

- The crises vary between them and therefore require different responses

- The crisis requires strategic planning to avoid undesirable developments in the organization's environment

- The crisis represents a threat to the organization or its reputation

In another division, the characteristics of the crisis were divided as follows: (Abu Fara, 2009), (Khudairy, 2003)

1. A clear lack of data and information during the crisis.

2. The crisis leads to a big surprise when it occurs.

3. The crisis is highly complex and overlapping as it occurs

4. The limited duration of the crisis, the crisis does not extend for a long time and if it is extended, it does not become a crisis and depends on the length of the crisis, according to the opinions of researchers about the size of the organization and the nature of its work.

In light of what it was mentioned, the researcher finds that the following conclusions can be drawn from the crisis as follows:

- The crisis represents a threat to both the organization and the workers.

- The crisis characterizes by lack of information and uncertainty.

- The crisis often occurs a shock at first and the situation of the organization shifts to a state of instability

- The crises' events are complex and difficult to control.

\section{Types of crises}

The understanding of the crisis - any crisis - and the way to deal with it depends heavily on the degree of knowledge of the type and nature of this crisis, and despite the multiplicity and diversity of crises, which wrote about it many scientists and researchers in the field of crisis management, but the classification of crises depends on the original aspect that is seen from it to the incident.

The crises can be divided into six types as the following:(Sirafi, 2003), (Ayazra and Benny Ahmed, 2008).

1. By content: Morality related to emotions and sensations, tangible related to tangible losses such as moral and tangible assets.

2. Depending on the possibility of utilization: Development of the individual succeeds to face them and gain experience, occasional damage and not to benefit from anything.

3. The severity of the impact: highly impact difficult to deal with disasters, weak impact easy to deal with it.

4. Stages of formation: emergence, escalation, integration, containment, the end

5. Time dimension: Frequent occurrences predictable, sudden and difficult to predict.

6. By the entity of damage: international, national crisis, specific society, organizational.

In another division of crisis types: (Azzam, 2004) 
- Technical / economic crises: include accidents and industrial disasters and computer malfunctions.

- External crises: include environmental accidents and natural disasters.

- Internal crises: include failure to learn with new positions, and ineffectiveness of communication and the sabotage works.

- Human, social and organizational crises: including terrorism, the works both of violence and vandalism.

In the view of the researcher from the previous presentation of the types of crisis that the crises vary according to the criterion that is adopted as well as the framework in which it occurs so it is important to identify the types of crisis facing the individual to be assessed in a manner linked to the crisis and to develop plans to deal with them based on that the evaluation.

\section{The historical development of the concept of crisis management}

The term of the crisis management originated in the science of public administration to refer to the role of the state in the face of sudden disasters and emergency conditions such as earthquakes, floods, epidemics, fires, armed conflicts, and all-out wars. In the field of the international relations refers to the way foreign policy which is managed in the face of tense international positions, and soon flourished within the science of management as a new method adopted by government agencies and public organizations to accomplish urgent and necessary tasks or to resolve emergency situations (Ahmed 2009) Therefore, the issue of crisis management has become a common phenomenon and a reality that imposes itself on the level of international conflict in the field of international politics, as a result of the interrelationships between countries, the complexity of conflict, the overlap of economic and ideological problems and the increasing interdependence between them (Abbas, 2007).

As a result of this method, the question arose about the possibility of transforming it into an integrated mode called crisis management, which works as a unit to deal with specific issues, namely, crises and difficult problems, by laying down the rules and the legal bases for it to become a specific administrative pattern in the face of multiple and successive crises (Arif ,2004).

In the context of the relationship between the public and private sectors and the exchange of interests and the entry of business sectors into multiple areas and in the diversity of crises and the extent of their impact could not be avoided by the private sector, but became the most confrontations of crises from the government sector because the crises threaten the survival and continuity of work, and thus became the role of the private sector played a key role in the face of recent crises (Ahmad ,2009)

In light of the above, it can be said that crisis management as a practice has existed since then as a method of solving problems, but as a modern theoretical framework, originated in the domain of public administration and then in the field of politics and international relations.

\section{Stages of the crisis}

The crisis in the cycle of its inception and its completion in several stages of the basic sequence of the evolution from the beginning of the emergence of an event as opposed to the confrontation and start dealing with the crisis life cycle can be used to predict the expected results of each stage of life and to take advantage of the intervention in time to deal with it, Consider among researchers the stages of the crisis in the titles but no difference in content 
Crisis managers should be aware of the stages of the crisis with a high concentration so that they can meet management challenges and their needs of different and vital dimensions at every stage (Sturges \& David, 1994). The stages of the crisis are intended to divide the crisis management function into separate sectors.

Crisis situations present extraordinary conditions needing prompt decisions. Same response to different crises is not appropriate. Every crisis needs that strategic action be taken in order to avoid or to minimize its undesirable results. Crisis management is a continuous effort. (Adnan, 2014).

(Coombs 2007) has divided the stages of the crisis into three phases according to the time base

1. Pre-Crisis Stage

It begins by focusing on early warning detection and prevention through teamwork, situation analysis, fact collection and employee training

2. Crisis Response Stage

At this stage, the crisis is dealt with and how to rebuild the reputation of the organization or the individual, because of the exposure of the organization to the damage is known and try to deal with it

3. Post- Crisis Stage

Are preparing for the coming crisis, and meet all the commitments made during the crisis phase including the provision of follow-up information, and can be radically changed at this stage after the completion of the crisis.

This division was adopted by a number of researchers, including Aboudi (2006), Maher (2006), Grant \& Robert 2010 and Lai (2010).

Mitroff's 1994) is agreed with Al-Nawaysa, 2006, that crisis consisting of five stages as follows:

1. Sense of crisis - detect signal Almost all crises are affected by early warning signals. If management can capture these signals, many crises can limit their appearance before they occur. This is the best way to manage the crisis.

2. Preparation / prevention: The goal is to pool efforts to reduce the continued and effective management of the crisis in its early stages.

3 - Containment of the crisis (damage containment): contain the impact of the crisis from spreading more

4. Recovery and recovery: The primary objective is to restore the normal state of the organization as soon as possible so as not to lose customers

5- Learning and evaluation: the process through which it reflects what has been accomplished so that the organization can manage the next crisis as it happens

In another classification (Fink 1986) the stages of the crisis into four stages:

1 - Portending stage

It is a warning stage, sometimes referred to as the pre-crisis stage. It is characterized by characteristics such as: help to make the sense of crisis more powerful and here the warning can be remedied before reaching the stage of crisis and is an important stage for the ease of crisis management or prepare for it once the sense of its beginnings

2 - The acute stage

This stage represents the point of no return when the warning ends and the crisis are reached. The importance of planning ahead and preparing for the crisis is highlighted. This planning provides sufficient time to confront, deal with and reduce the impact of the crisis.

3. Chronic stage 
At this stage, the causes of the crisis, the assessment of the damage and the determination of responsibility are confirmed. This stage is a re-evaluation and taking of appropriate measures. The Organization may be undergoing financial turmoil, reorganization or even bankruptcy.

4. Solution stage

At this stage the factors causing the crisis begin to fade, the organization returns to the stage of natural equilibrium before the crisis, so this stage represents the last stages of the crisis that reach after the escalation of its framework

Some researchers have relied on this model in building their studies Larson and Rudwall 2010), (Zhu 2011)

Note that there is a strong similarity between the Mitroff (1994) division and the Fink (1986) division. The detection phase of early warnings can reflect part of the warning phase, and the difference lies in the degree to which the Mitroff model reflects the focus on detection, , While the Fink model focused on crises that could be prevented at this stage.

Mitroff explained each of these stages in an effective and practical manner. There is also a correlation between the restoration of equilibrium, activity and the chronic phase. Both determine the need for reprogramming processes. The Mitroff model focuses on how the crisis team reinvigorates and balances the organization. The Fink model suggests that organizations are reacting at varying speeds.

The learning phase or the solution phase is a solution to the crisis. The Mitroff learning stage focuses on crisis management as well as the description of the crisis. For the latter, it is a continuation of the restoration of balance and activity. Communication and follow-up with stakeholders moves from recovery to learning Evaluation, model Fink shows that the solution phase occurs when the end of the crisis.

The main difference between these two models is the comparison of the latter. The Mitroff model suggested what the crisis manager should do at each stage and focused on the progress of crisis management efforts and activity. The Fink model adopted the descriptive approach and the characteristics of each stage, the crisis.

Naturally, both Fink (1986) and Mitrof (1994) correspond to the pre-crisis Coombs (2007) model, which includes all concepts of pre-crisis preparedness, warning detection, prevention and preparedness, and the warning stage. The crisis phase includes actions to be taken The period of crisis, the period of containment of damages, recovery of activity, the stage of crisis and the chronic stage are covered by this stage. The post-crisis phase reflects the post-crisis period, and both the learning and evaluation phase are covered.

Table 2 A comparisons between the various stages described previously for researchers

\begin{tabular}{|l|l|c|}
\hline \multicolumn{1}{|c|}{ Coombs (2007) } & \multicolumn{1}{|c|}{ Mitroff (1994) } & Fink (1986) \\
\hline \multirow{2}{*}{ Pre-crisis phase } & Discover alarms & Preparedness and prevention \\
\cline { 2 - 3 } & Warning phase & \\
\hline \multirow{2}{*}{ The stage of the crisis } & Containment & Crisis \\
\cline { 2 - 3 } & Restore balance and activity & Chronic stage \\
\hline Post-crisis & Learning and evaluation & The solution stage \\
\hline
\end{tabular}

\section{Obstacles of successful crisis management}

The obstacles that impede the crisis management process from achieving its objectives in eliminating the crisis can be classified into four sections, which are the most common among researchers (Septi 2002) and (Al Qatawneh 2005 ) 
1- Organizational constraints: lack of clear definition of authority, differing culture among individuals, poor training, lack of support by senior management of the crisis management process.

2 - Obstacles related to information: related to the validity of information in terms of diagnosis of accuracy, to secure sources or to withhold part of the information required of the decision maker. 3- Constraints related to communication: The difficulty of transferring and exchanging information from within and outside the organization and the limited use of modern communication systems to deal with crises.

4 - Human obstacles: relating to individuals, including the excessive reliance on the view of the group, the belief that the importance of crisis management, the failure of individuals to know and understand the nature of the dangers.

Al-Abadala 2002 added to the previous obstacles:

1 - Environmental constraints: related to the surrounding environment, which faces management to limit its effectiveness in facing the crisis, such as pollution caused by industrial waste and pesticides, and the lack of environmental awareness of citizens and the lack of awareness campaigns enough to deal with crises.

2 - Economic constraints: related to the current economic situation, whether internally or externally, such as the small financial allocations, rising costs of raw materials and maintenance and lack of financial resources.

3 - Technological constraints: related to the technical and technical factors of the organization, which is a barrier to the crisis, such as the use of modern technologies such as the Internet and others and the lack of advanced devices and lead to a mistaken diagnosis of the crisis.

Based on the various obstacles encountered in the success of the crisis management process, which are difficult to enumerate but which are listed as one of the most common and influential (humanitarian, organizational and information communication), additional obstacles (economic, environmental, technological) have been added due to the complexity and interconnectedness of crises, Which must be added by the researcher.

Factors influencing the success of crisis management

The researchers agreed with (Sabti 2002), (Aboudi 2006), (Qatawneh 2005) and (Maher 2006) that crisis management needs the following factors in order to be successful:

1. Establish a comprehensive and integrated database of information and data for all activities of the Organization.

2. Understand the importance of time

3. Provide an early and efficient risk monitoring system

4. A constant readiness to confront crises through the development of capacities and the mobilization of resources available to the Organization

3. An efficient and effective communication system

\section{Negative and positive impacts of crises}

First: negative effects

1. The creation of crises is an endless responsibility for organizations, and the estimation of the cost of damage resulting from them is impossible to calculate accurately.

2 - The crises lead to anxiety and panic, resulting in psychological and physical exhaustion of workers (Maher 2006).

3. Expect loss by FAO and shareholders (Coombs 2004) 
4 - The crisis may extend to unexpected aspects and extend the negative impact of new parties (Qatoona 2005).

5 - Lead to a state of tension in a short period, resulting in inconsistent reactions and decisions that are not rational or objective (Qatawneh 2005)

Second: Positive Effects

\section{Crises management strategies}

Iordache 2013 stated that nowadays, the management of the crisis became an essential part in the hospitality's industry, being an efficient control instrument, for anticipating and knowing what type of threats are in a business with hotels to know how to control.

Despite the multiplicity of types and forms of crises, but the aim of facing them is to limit the intensity of their impact by studying the causes and factors, and the director of crisis management to choose the appropriate strategy to deal with the potential risk that the crisis may cause, the higher the risk is likely to Crisis strategies should also try to accommodate the victims affected by the crisis (Coombs). Crisis strategies should also mitigate damage to good reputation by focusing on the organization taking the necessary and correct actions to deal with it (Ajwa and Fred 2005).

\section{Traditional strategies}

(Maher 2006) Characteristise of the nature of the crisis and the variety of traditional strategies and referred to in Figure 1.

Figure 1: Characteristic of the nature of the crisis

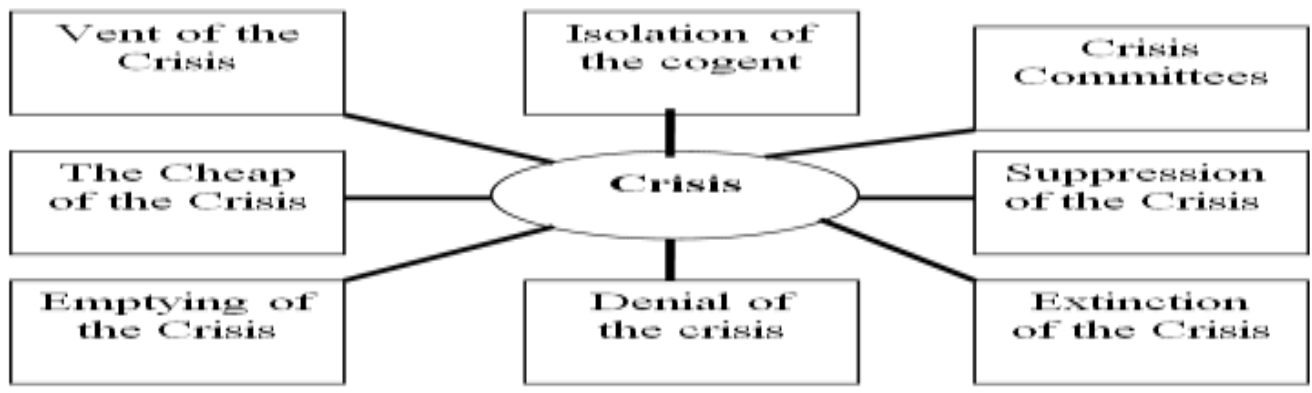

Source: (Maher 2006)

1 - Denial of the crisis: the simplest traditional ways as the official declares that there is no crisis and that the situation is better and better conditions and can not be better than it is now, and called the method of media blackout of the crisis and use this method in the presence of autocratic administration is very authoritarian (Khadairy 2003), (Coombs \& Holladay, 1996: 284)

2 - Suppressing of the crisis: a quick move against the forces of the crisis in order to close the outlets of the basic elements of the crisis, a strategy that indicates that the organization used by it authoritarian and authoritarian (Maher 2006).

3 - The formation of committees to study the crisis: It occurs when the organization lacks sufficient information about the forces involved in the crisis and the main objective of the formation of committees to identify the basic elements.

4. The Cheap of the crisis: Here the organization recognizes the occurrence of a certain crisis and reduces it as if it is simple and under control and will be dealt with in appropriate ways and this method actually works in simple, limited and partial crises when the organization is able to remedy the matter after the underestimation and reduce the size (Maher 2006), (Coombs 2012) 
5 - Emptying of the crisis: There is no doubt that the multiplicity of crisis paths contribute to reduce the risk and therefore emptied the crisis through three stages of the first is witnessing a violent confrontation of the necessary driving forces and specifically to the extent of coherence, and the second phase and determine through which the alternative goals of each direction of the crisis trends to facilitate the deal With each of them separately and in the final stage the process of attracting and negotiating all these trends begins within the framework of a comprehensive vision (Al-Khudairi 2003).

\section{Non-traditional strategies (modern)}

Gilpin \& Murphy 2008Characterise strategies emerged as a result of the evolution witnessed by the administrative entity, especially for the different type of crisis, its form and nature, which are different from traditional strategies and are more effective and suitable for the spirit of the times and compatible with the variables

Figure 2: Modern Strategies for Crisis Management

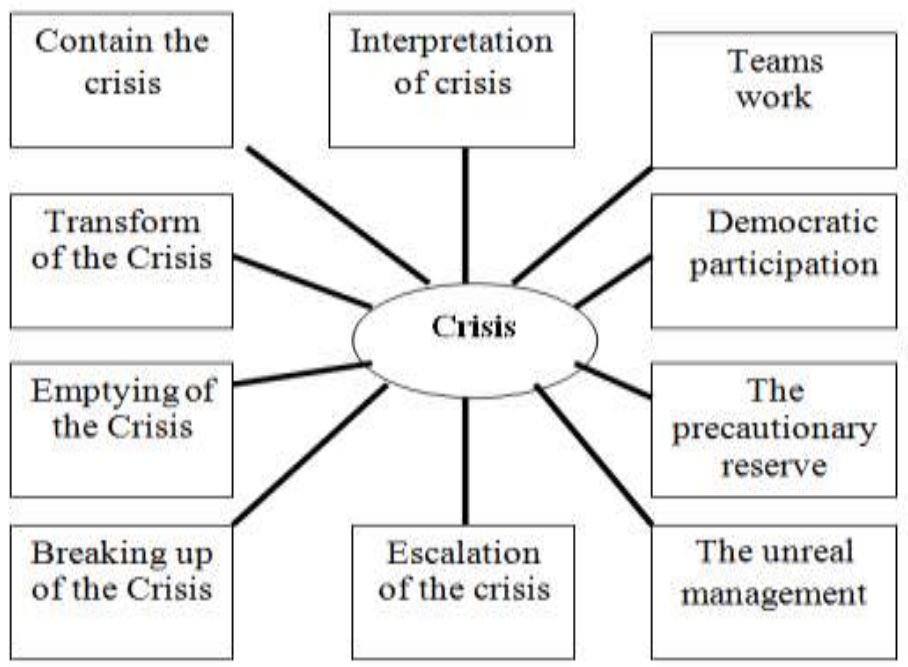

Source: (Gilpin \& Murphy 2008)

\section{Track Change (Transformation) Strategy}

It is used to deal with severe crises that are difficult to contain by creating a spirit of challenge and openness in individuals to compensate for losses and achieve the best results.

2 - Strategy to break up the crisis

This strategy is based on knowing all the details of the factors that cause the crisis by identifying the conflicting frames and the potential benefits and then dividing the crisis effect into multiple solvable parts. This method will solve the huge and serious crisis.

3. Crisis containment strategy

Restricting the crisis to a limited scope and freezing it at a stage that can be absorbed and exhausted by its power, by focusing on listening to the demands of the crisis forces and negotiating with them through official negotiation channels representing them such as the unions and the parties.

4. Strategy for emptying the crisis:

One of the most successful non-traditional ways of dealing with crises is that the crisis revolves around a certain content. Therefore, without agreement on this content, it is difficult to sustain 
the pressure that leads to the crisis. It is based on identifying the causes of the crisis, whether religious, economic or political.

5. Teams work: the most common methods used when the crisis and overlap through the supervision of specialists in different areas to confront them scientific confrontation and not to lose points.

6. The precautionary reserve: resorted to industrial organizations that need raw materials for production processes and so we can face the shortage of raw materials.

7. Escalation of the crisis: This method is used when crises are not clear and raise many conflicting possibilities and a variety of trends, especially when there is a bloc at the stage of forming the crisis, although the nature of interests and goals and objectives imperative existence of this bloc, but may allow the beginning of the formation of the crisis, And to implement this configuration is working to escalate the crisis in one way or another until it reaches the point of conflict of interest as the bloc disintegrates and each team moves to another direction.

7. Democratic participation: This method is very influential when the crisis deepens in human violence and is usually used in societies that are characterized by individual freedom, such as economic, political and social free behavior, declaring the extent of the crisis and the danger and the way to confront it and determine the duties and responsibilities of society members in order to eliminate crises.

8. Breaking up of the crisis: called the internal explosion of the crisis or direct conflict and used when the organization sees that there is a devastating threat to the organization and threatens its survival, and here the organization resort to the internal bombing of the elements of the crisis and its engines and follow the following steps: severely hit the supporters of the crisis and attack on the thought of the crisis, The crisis of the two drivers and supporters, targeting the two powerful drivers of the crisis by excluding them and perhaps liquidating them and finding alternative leaders to a more moderate crisis that can turn the crisis from their negative efforts to other positive tracks.

9. Enormous abundance: one of the psychological methods used by the decision-maker to deal with violent crises, rapid and successive events, which threatens the destructive risk of the administrative entity with the existence of a psychologist accompanying the worker may create a state of panic and stimulate the factors of the crisis and examples of crises catering to a commodity Such as bread, flour, etc.

Bodosca, 2015, stated the effects of the crisis and the suitable business strategies

Table 3: the effects of the crisis and the suitable business strategies

\begin{tabular}{|c|c|}
\hline Effects of the crisis & Business strategies \\
\hline Shift towards cheaper accommodation & Reinforcing promotion \\
\hline Opting for fewer nights & $\begin{array}{c}\text { Credit facilitation, free night for longer stays, } \\
\text { Upgrading of packages ,i.e. half board to full board or } \\
\text { higher room standard }\end{array}$ \\
\hline $\begin{array}{c}\text { Decrease for the business tourism(decrease } \\
\text { in the organization of smaller seminars and } \\
\text { training courses }\end{array}$ & Fiscal incentives \\
\hline Giving up on optional activities & $\begin{array}{c}\text { Free nautical activities, wider choice of free sport } \\
\text { activities, more options for leisure activities }\end{array}$ \\
\hline Smaller revenues for business & $\begin{array}{c}\text { Lay off employees, diminished funds for training the } \\
\text { staff in improving service delivery }\end{array}$ \\
\hline
\end{tabular}

Source: ( Bodosca 2015) 


\section{Research Methodology}

Based on the above explanation of the concept of crises and methods of dealing with them traditionally and recently, the researcher preferred to focus on the most successful modern strategies in the face of crises agreed by the researcher.

It can be applied to the current study community, which is as follows:

- (changing path strategy)

- (crises fragmentation strategy)

- (containment crisis strategy)

- (exhausting crisis strategy)

- (reserve mobilization strategy)

The questionnaire was designed to capture information about the research to meet the needed objectives. Respondents were asked to indicate their level of agreement with each question on four choice Likert-scale metric.

Table 4: the value of Likert scale

\begin{tabular}{|c|c|}
\hline Mean & Direction \\
\hline $1-1.80$ & Strong disagree \\
\hline $1.80-2.60$ & Disagree \\
\hline $2.60-3.40$ & Neutral \\
\hline $3.40-4.20$ & Agree \\
\hline $4.20-5.00$ & Strong agree \\
\hline
\end{tabular}

\section{Secondary data}

This study relies on the theoretical side using multiple scientific sources relating the subject of Crisis Management, the strategies of crises management and the crisis management strategy (changing the course, the tactical reserve, emptying the crisis, breaking up the crisis and containment the crisis) where the management of the most important Egyptian hotels depends on and what is the level of its enforcement.

\section{Primary data}

This study used the descriptive method to collect data. The collection of data was mainly based on questionnaire; The questionnaire was designed to capture information about the research to meet the needed objectives. Respondents were asked to indicate their level of agreement with each question on four choice Likert-scale metric.

\section{Description of study population and sample}

This study used the descriptive method to collect data. The collection of data was mainly based on questionnaire. Some 96 questionnaire forms were distributed to a random sample for the top management and staff will be used in this research in order to gain the desired data about the strategic crisis management process. The collected data will be statistically analyzed by using different measures including descriptive ones, such as frequencies, Mean, and standard deviation as well as cross tab.

\section{Data analysis}

There is a significant difference in relative importance of opinions of the study sample for Changing Path Strategy at level of significant less than (0.01). There is a significant difference in relative importance of opinions of the study sample for Reserve Mobilization Strategy at level of significant less than (0.01). 


\section{Reliability statistics}

To test the reliability and stability of the questionnaire and to be sure of the reliability of respondents in answering questions, the Cronbach's alpha $(\alpha)$ was used to achieve the previous proposed objectives (Develles RF (1991). The value for cronbach's alpha is located between $(0$, 1) and this value clarifies the extent of correlation between answers. The closer the Cronbach's Alpha coefficient is to 1 , the greater the internal consistency of the items on the scale. The accepted value of Cronbach's is between $0.7,0.8$ values, substantially lower values indicate unreliable scale.

Table 5: The value of Cronbach's Alpha

\begin{tabular}{|c|c|}
\hline Cronbach's alpha & Internal consistency \\
\hline$\alpha \geq 0.9$ & Excellent \\
\hline $0.9>\alpha \geq 0.8$ & Good \\
\hline $0.8>\alpha \geq 0.7$ & Acceptable \\
\hline $0.7>\alpha \geq 0.6$ & Questionable \\
\hline $0.6>\alpha \geq 0.5$ & Poor \\
\hline $0.5>\alpha$ & Unacceptable \\
\hline
\end{tabular}

\section{Statistical Validity}

Validity refers to how well a test measures what it is purported to measure. Internal validity is the degree to which the examined effects actually are caused by the presented advertising execution and not be other external factor (Brain, Willnat, Manheim and Rich, 2011).

Table 6: the reliability value \& the validity value

\begin{tabular}{|c|c|c|c|}
\hline \multicolumn{2}{|c|}{ The characteristics of the study sample } & Frequency & Percent \\
\hline \multirow{3}{*}{ Gender } & Male & 63 & 65.6 \\
\hline & Female & 33 & 34.4 \\
\hline & Total & 96 & 100 \\
\hline \multirow{5}{*}{ Age } & Younger than 30 years & 6 & 6.3 \\
\hline & From $30-40$ years & 23 & 24.0 \\
\hline & From $40-50$ years & 52 & 54.2 \\
\hline & From $50-60$ years & 15 & 15.6 \\
\hline & Total & 96 & 100 \\
\hline \multirow{4}{*}{ Education level } & Degree & 54 & 56.3 \\
\hline & Masters & 30 & 31.3 \\
\hline & Doctoral & 12 & 12.5 \\
\hline & Total & 96 & 100.0 \\
\hline \multirow{3}{*}{ Specialization } & Business Administration & 53 & 55.2 \\
\hline & Tourism and Hotels & 43 & 44.8 \\
\hline & Total & 96 & 100.0 \\
\hline \multirow{4}{*}{ Occupation } & Hotel Manger & 3 & 3.1 \\
\hline & Hotel Vice-manager & 6 & 6.3 \\
\hline & Departmental Director & 87 & 90.6 \\
\hline & Total & 96 & 100.0 \\
\hline \multirow{4}{*}{ Experience of Years } & Less than 5 years & 7 & 7.3 \\
\hline & $6-10$ years & 22 & 22.9 \\
\hline & $11-15$ years & 32 & 33.3 \\
\hline & More than 15 years & 35 & 36.5 \\
\hline
\end{tabular}


International Journal of Heritage, Tourism and Hospitality Vol. (12), No. (1/2), March, 2018 By: Faculty of Tourism and Hotels, Fayoum University

\begin{tabular}{l|c|c|c|c|c|}
\hline \multicolumn{1}{|c|}{ Total } & \multicolumn{2}{c|}{96} & \multicolumn{2}{c|}{100.0} \\
\hline \multicolumn{1}{|c|}{ Items } & Mean & $\begin{array}{c}\text { Std. } \\
\text { Deviation }\end{array}$ & $\begin{array}{c}\text { Difference } \\
\text { coefficient }\end{array}$ & Sort \\
\hline $\begin{array}{l}\text { Trevious crises have had an impact } \\
\text { on the hotel's work performance. }\end{array}$ & 3.98 & .54 & 13.62 & 1 \\
\hline $\begin{array}{l}\text { The management of the hotel deals } \\
\text { with crises based on the appropriate } \\
\text { options for its strength. }\end{array}$ & 3.93 & .73 & 18.55 & 2 \\
\hline $\begin{array}{l}\text { Hotel management uses a strategy to } \\
\text { change course when faced with } \\
\text { uncertain crises. }\end{array}$ & 3.23 & .80 & 24.80 & 4 \\
\hline $\begin{array}{l}\text { The management of the hotel is } \\
\text { trying to draw the attention of } \\
\text { customers to a subject different from } \\
\text { the subject of the crisis is often } \\
\text { positive. }\end{array}$ & 3.10 & .57 & 18.42 & 5 \\
\hline $\begin{array}{l}\text { Track change strategy has a positive } \\
\text { impact on the hotel's expected } \\
\text { performance }\end{array}$ & 3.66 & .74 & 20.14 & 3 \\
\hline $\begin{array}{l}\text { Chi square } \\
\text { Sig. }\end{array}$ & & & & \\
\hline
\end{tabular}

The above table show: There is a significant difference in relative importance of opinions of the study sample for Changing Path Strategy at level of significant less than (0.01).

Table 8: Demonstrate the mean and std. deviation for Reserve Mobilization Strategy

\begin{tabular}{|l|c|c|c|c|}
\hline \multicolumn{1}{|c|}{ Items } & Mean & Std. Deviation & $\begin{array}{c}\text { Difference } \\
\text { coefficient }\end{array}$ & Sort \\
\hline $\begin{array}{l}\text { Hotel management recognizes the } \\
\text { importance of a "safety limit" for food } \\
\text { and beverage stocks. }\end{array}$ & 4.27 & .607 & 14.22 & 1 \\
\hline $\begin{array}{l}\text { The hotel usually provides an adequate } \\
\text { stock of food and drinks. }\end{array}$ & 4.01 & .718 & 17.91 & 4 \\
\hline $\begin{array}{l}\text { The hotel management usually provides } \\
\text { a stock of cash for crises. }\end{array}$ & 4.13 & .548 & 13.27 & 3 \\
\hline $\begin{array}{l}\text { The hotel management believes that the } \\
\text { tactical reserve strategy is necessary to } \\
\text { cope with crises. }\end{array}$ & 4.15 & .740 & 17.83 & 2 \\
\hline Chi square & \multicolumn{2}{|c|}{44.750} \\
\hline Sig. & \multicolumn{2}{|c|}{0.000} \\
\hline
\end{tabular}

The above table show: There is a significant difference in relative importance of opinions of the study sample for Reserve Mobilization Strategy at level of significant less than (0.01).

Exhausting Crisis Strategy

Table 9: Demonstrate the mean and std. deviation for Exhausting Crisis Strategy

\begin{tabular}{|c|c|c|c|c|}
\hline Items & Mean & Std. Deviation & $\begin{array}{c}\text { Difference } \\
\text { coefficient }\end{array}$ & Sort \\
\hline The hotel management is able to analyze & 3.64 & .919 & 25.25 & \\
\hline
\end{tabular}


International Journal of Heritage, Tourism and Hospitality Vol. (12), No. (1/2), March, 2018 By: Faculty of Tourism and Hotels, Fayoum University

\begin{tabular}{|l|c|c|c|c|}
\hline $\begin{array}{l}\text { the content and content of the crisis and } \\
\text { deal with it. }\end{array}$ & & & 1 \\
\hline $\begin{array}{l}\text { The management of the hotel resort to } \\
\text { recognizing the existence of the crisis in } \\
\text { principle, to ensure the discharge } \\
\text { (processed). }\end{array}$ & 3.26 & .909 & 27.88 & 3 \\
\hline $\begin{array}{l}\text { The management of the hotel will } \\
\text { establish temporary alliances with the } \\
\text { necessary elements to deal with them. }\end{array}$ & 3.07 & 1.039 & 33.84 & 4 \\
\hline $\begin{array}{l}\text { The hotel management believes that the } \\
\text { strategy of emptying the crisis is an } \\
\text { appropriate solution to the crisis. }\end{array}$ & 3.50 & .940 & 26.86 & 2 \\
\hline Chi square & & \multicolumn{2}{|c|}{26.625} & \\
\hline Sig. & & & \\
\hline
\end{tabular}

Table 10: Demonstrate the mean and std. deviation for Crisis Fragmentation Strategy

\begin{tabular}{|l|c|c|c|c|}
\hline \multicolumn{1}{|c|}{ Items } & Mean & Std. Deviation & $\begin{array}{c}\text { Difference } \\
\text { coefficient }\end{array}$ & Sort \\
\hline $\begin{array}{l}\text { The hotel management has sufficient } \\
\text { information about the nature of the } \\
\text { crisis it faces. }\end{array}$ & 2.97 & 1.349 & 45.42 & 4 \\
\hline $\begin{array}{l}\text { The hotel management undertakes } \\
\text { the necessary studies to identify the } \\
\text { conflicting interests that cause the } \\
\text { crisis. }\end{array}$ & 3.16 & 1.417 & 44.84 & 3 \\
\hline $\begin{array}{l}\text { The hotel management relies on } \\
\text { specialists to break up the crisis. }\end{array}$ & 4.03 & 1.061 & 26.33 & 1 \\
\hline $\begin{array}{l}\text { The hotel is usually able to } \\
\text { fragmentation (fragmentation) the } \\
\text { crisis successfully. }\end{array}$ & 3.45 & 1.089 & 31.57 & 2 \\
\hline Chi square & & & \\
\hline Sig. & \multicolumn{2}{|c|}{0.000} \\
\hline
\end{tabular}

Table 11 Demonstrate the mean and std. deviation for Containment Crisis Strategy

\begin{tabular}{|l|c|c|c|c|}
\hline \multicolumn{1}{|c|}{ Items } & Mean & Std. Deviation & $\begin{array}{c}\text { Difference } \\
\text { coefficient }\end{array}$ & Sort \\
\hline $\begin{array}{l}\text { The management of the hotel provides } \\
\text { information on the adoption of specialized } \\
\text { teams from within to contain the crisis. }\end{array}$ & 3.19 & 1.332 & 41.76 & 3 \\
\hline $\begin{array}{l}\text { Over the past years, the hotel management } \\
\text { has managed to successfully contain crises. }\end{array}$ & 3.33 & 1.053 & 31.62 & 2 \\
\hline $\begin{array}{l}\text { The hotel management negotiates with the } \\
\text { causes of the crisis to contain them. }\end{array}$ & 2.86 & 1.211 & 42.34 & 4 \\
\hline $\begin{array}{l}\text { The staff of the hotel are doing the required } \\
\text { efforts to help contain the crisis }\end{array}$ & 3.66 & .678 & 18.52 & 1 \\
\hline Chi square & \multicolumn{4}{|c|}{39.938} \\
\hline Sig. & \multicolumn{4}{|c|}{0.000} \\
\hline
\end{tabular}




\section{Discussion}

Management of the Egyptian hotels doesn't depend on the hypothesis of the study: changing path strategy, crises fragmentation strategy, containment crisis strategy, exhausting crisis strategy and reserve mobilization strategy.T test was used to measure this hypothesis and the results were as follow:

\begin{tabular}{|c|c|c|c|c|c|c|}
\hline $\begin{array}{l}\text { Sample } \\
\text { number }\end{array}$ & $\begin{array}{c}\text { Mathematical } \\
\text { mean }\end{array}$ & $\begin{array}{l}\text { Standard } \\
\text { deviation }\end{array}$ & $\begin{array}{c}\begin{array}{c}\text { Freedom } \\
\text { degree }\end{array}\end{array}$ & $\mathrm{T}$ values & $\begin{array}{c}\text { Probable } \\
\text { value }\end{array}$ & Conclusion \\
\hline 96 & 3.8367 & 0.60890 & 95 & 73.928 & 0.0000 & Hypothesis accepted \\
\hline
\end{tabular}

\section{Research conclusion}

This study has provided a significant insight about crisis management culture and strategies in the hospitality in Egypt. Results have revealed a disturbing trend in crisis management readiness in the hospitality in Egypt. The culture of crisis management in Egyptian tourist agencies affects the strategies adopted by the agencies that focus on crisis handling when it is on occurrence .Insurance was the first crisis management strategy used in the Egyptian hospitality and they perceived it as the most important strategy too. Most of the Egyptian hospitality adopts a defensive crisis management strategy to wait and react later on. And the major ratio of the agencies use price policy as a crisis handling or coping instrument. In general, all the correlations for importance and usage were positive and statistically significant (at p0:05), suggesting that there is a certain level of consistency in the crisis-management behavior of managers. However respondents continue to point at the budgetary barriers to the provision of adequate resources in support of crisis management in their enterprises.

Most of the Egyptian hospitality adopts a defensive crisis management strategy to wait and react later on. And the major ratio of the agencies use price policy as a crisis handling or coping instrument. The crisis management practices in the Egyptian hospitality are immature and require major strategic planning actions from both the governmental tourist organizations and private hospitality.

\section{Research Recommendations}

- The Egyptian hospitality need to develop crisis management practices based on the right and complete understanding of crisis management as an approach not only to fire fight crisis when occurs but also to prevent and avoid crisis. They need to understand the importance of crisis management to reap the full advantages of crisis management.

- The Egyptian hospitality need to integrate crisis management within the strategic planning for the enterprise.

- The Egyptian hospitality also need to use more preventive and handling strategies to sustain their performance under the times of uncertainty. The role of the tourist governmental authorities is very important for improving crisis management practices in the tourism industry in Egypt.

- The governmental authority should provide technical support for the hospitality in the context of crisis management. It is strongly recommended to activate the role of the Disaster Fund under the Egyptian Ministry of Tourism and Egyptian Tourism Federation (ETF) and to establish an organization that takes over crisis insurance in the tourism sector.

- Egyptian hotels should prepared for crisis situations; Managing costs during crisis; Make full 
use of local advice; Maintaining good communication with guests; and the Use of technology to enhance hotel security.

- Egyptian Ministry of Tourism should Concerning with the destination image, a positive relationship with the mass media is regarded as critical in the recovery phase it is particularly important to manage communication and perceptions through a crisis communication and marketing strategy.

- The promotion of domestic tourism and here in particular the marketing of specific niche products as well as the development of new forms of tourism such as sustainable tourism and ecotourism. Coordination and collaboration between key stakeholders also appear to be crucial for the effective management of a crisis situation

- Egyptian hotels should apply the Yield Management (revenue management), that was created to increase net income while maximizing occupancy

\section{Research implications}

- Technology can be used to enhance the overall hotel security and cameras in corridors as well as other public spaces are the norm today. Well positioned cameras and other visible security measures are welcomed by the guests as they increase the perception of security

- The implementation of energy efficiency measures can bring the hotel a number of advantages, not only economic but environmental as well. Energy management starts by collecting the necessary energy consumption data.

- The most practice partnerships with event organizers, seminars, workshops, companies can make regular hotel guests. This approach is beneficial for identifying new market segments and thus better targeting.

- Promotion campaigns refers not only to accommodation services, but also to those offered by restaurants, health clubs, conference rooms and meeting sites.

- Applying ancient tactics to create more personal connections, placing a greater effort to develop a lasting business relationship. This strategy should be applied especially because in recent years the development of the Internet has led to depersonalization hoteliers relationships with customers. Most hotels are focused on prioritizing policies time, so as to become more productive business.

\section{Refferences}

$$
\begin{aligned}
& \text { المراجع العربية } \\
& \text { أبو فارة، يوسف أحمد (2009): إدارة الأزمات مدخل متكامل، الطبعة الأولى، عمان، إثراء للنشر . }
\end{aligned}
$$

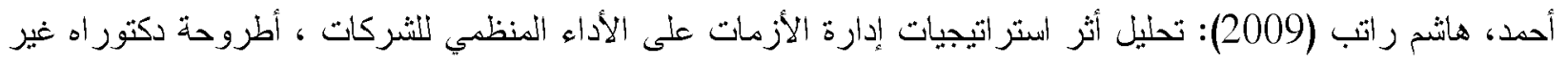

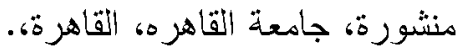

$$
\begin{aligned}
& \text { جاد الله محمود (2008): إدارة الأزمات، الطبعة الثانية، القاهرة، دار اسامة للنشر و التوزيع. } \\
& \text { الخشاري، شاكر جاد الله و القطب، محي الدين (2007): فاعلية نظام المعلومات الإدارية واثرها في إدارة الأزمات: دراسة } \\
& \text { ميدانية في الثركات الصناعية الأردنية، المجلة الأردنية في إدارة الأعمال، الجامعة الإردنية، عمان، الاردن، }
\end{aligned}
$$

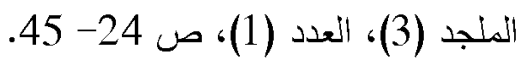

$$
\begin{aligned}
& \text { الخضبري، محسن أحمد (2003): إدارة الأزمات: علم امتلاك كامل القوة في أشد لحظات الضعف، الطبعة الأولى، } \\
& \text { القاهرة، مجموعة النيل العربية. }
\end{aligned}
$$




$$
\begin{aligned}
& \text { الصبيرفي، محمد عبد الفتاح (2003): مفاهيم إدارية جديدة، الطبعة الأولى، القاهرة، دار الكتاب. } \\
& \text { العارف، نادية (2004) : الإدارة الاستر اتيجية، القاهرة، الار الجامعية. } \\
& \text { عباس، صدلاح (2007): إدارة الأزمات في المنثآت التجارية، الإسكندرية، مؤسسة شباب الجامعة. }
\end{aligned}
$$

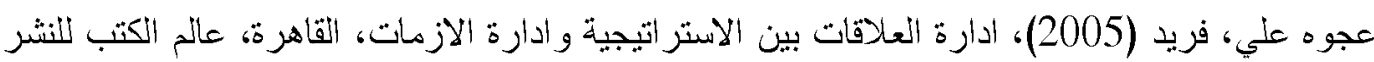

$$
\begin{aligned}
& \text { عز ام، ماجد كامل علي،(2004)، ادارة الازمات فس قطاع الصناعات الدوائية، رسالة ماجستير غير منشورة، كلية }
\end{aligned}
$$

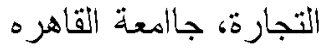

$$
\begin{aligned}
& \text { عياصرة، معن محمد، وبني أحمد، مروان (2008): إدارة الصر اع والأزمات وضغوط العمل، الطبعة الأولي، عدان، دار }
\end{aligned}
$$

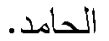

$$
\begin{aligned}
& \text { القطاونة، ايمن سليمام، (2005)، ادارة الازمات في الثشركات التجارة، رسالة دكتور أة غير منشورة، جامعة مؤتة، الازردن. } \\
& \text { ماهر ، احمد، (2006)، ادارة الازمات، الاسكندرية، الدار الجامعية. } \\
& \text { النو ايسة، رياض حسين، (2006)، نموذج مقترح لادارة الازمات في وزارة التربية والتعليم في ضوء الو اقع والاتجاهات } \\
& \text { الادارية المعاصرة، رسالة ماجستيرغير منشورة، جامعة عمان، الاردن. }
\end{aligned}
$$

Aboudi, H. (2006). Tourism in Crisis. Journal of Travel Research, 2(1), 59

Abu Fara, A. (2009). Tourism Marketing, Tourism Research journal, 12 (3): 27

Adnan, M. (2014), Pakistan's Crisis Management: Examining Proactive and Reactive Strategies, Journal of Political Studies, Vol. 21, No. 1, pp. 161:177.

Ahmed, S. S. (2002). Tourism in Egypt, Alahram press, Cairo, 35

Al Khashaly, H. and Al Kotb, A. , (2007). Crisis management: A. marketing Journal, 3(1), 24.

Al-Abadala, A. (2002). Destination Marketing, Tourism Research Journal, 12: 27

Al-Sirafi.M.. (2008). Crisis Management in Hospitality. Cairo: Amer Press. 28

Bodosca,L.S.(2015), Sustainable Decision Making Under the Crisis for Tourism Businesses: A Survey of the Literature for EU Member States, Theoretical and Applied Economics, Management Journal ,Vol. 4, No. 1, pp. 42-61.

Brains Willnat, Manheim Rich. Empirical Political Analysis 8th edition. Boston, MA: Longman p. 2011; 105.

Carthage, S. (2007). Strategies mangement. Strategic Management Journal, 1 (3), 27

Collison,P and Parcell, W, (2001). A Crisis Analysis, Information Systems Journal, 34(6)

Coombs M., L. (1961). The Crisis. London: Spaice Publishers. 191

Coombs, T. (2007a). Protecting organization reputations during a crisis: the development and application of situational crisis communication theory. Corporate Reputation Review.10 (3):163-176.

Coombs, T. Holladay, S. (1996). Communication and attributions in a crisis: An experimental study in crisis communication. Journal of Public Relations Research,8(4): 279-295

Coombs, W. T. (2007b). Ongoing crisis communication: planning, managing, and responding. (2ed). CA: Sage.

Coombs, W. T. (2012). Ongoing crisis communication: planning, managing, and responding. (3ed). California.Sage Publications.

Coombs.T. (2004). West pharmaceuticals explosion structuring crisis discourse knowledge. Public Relations Review. 30(4): 467-473

Coombs.T. (2006). The protective powers of crisis response strategies: managing reputational assets during a crisis. Journal of Promotion Management, 12(3/4):241-260

DeVellis, R. (1991). Scale development. Applications and theory.

Faulker,D. (2001). Crisis Management in the Hospitality Industry. UK: Butterworth Heinemann. 
Fink, S.(1986). Crisis Management: Planning for the Inevitable. NY: New Jersey:American Management Association, pp, 20-25.

Fishman, Donald, A. (1999).Valujet flight 592: Crisis Communication theory blended and extended. Communication Quarterly. 47(4): 345-375.

Ford, M. \& Angermeier, I.I. (2004). From Crisis Prone to Crisis Prepared: A framework for crisis management. Executive Journal, 7(1), 48-59.

Gilpin. D, Murphy.P. (2008). Crisis management in complex world, New York, USA. Oxford University.

Goel, Suresh. (2009). Crisis management. India. Global India Publication.

Grant, Robert, M. (2010).Contemporarily strategy analysis. (7ed). UK.Willey.

Henderson, W. T. (2006). On going crisis communication: planning, managing, and responding. London: Sage Publications.

Horváth,D, Mitev,A. and Bauer.A,(2014), Winning Media Strategies in the Time of the Economic Crisis, Vol. 45, No. 2, pp.46-52.

Human Resources Development Institute,( 2011). Available at http:// Institute.mcot.net/view.php?id=12455 (Accessed June 12, 2018 (11:21)

Iordache, C.(2013), Management strategies of the financial-economical crisis in the hotel's domain, Theoretical and Applied Economics, ,Vol. XX, No. 9 , pp. 115-126.

Kim, D. (1998). Restoring Hospitality Destinations in Crisis: A Strategic Marketing Approach. Australia, A New Case Study Model. Environment Magazine, 52(5), 36-41.

Lai, Y. (2010). An application of situational crisis communication theory: case study of AN TJX- LEAK Of customers information, (Unpublished Master Thesis) Ball State University, INDIANA, USA.

Larson, J. Rudwall, P. (2010). Crisis management: Media's perception of crises in organizations. (Unpublished Bachelor Thesis). Lulea University of Technology.(Online) . Available at: http://epubl.ltu.se/1402-1773/2010/133/LTU-CUPP-10133-SE.pdf

Laws, M., R. \& Prideaux, W. (2007). What Passes as a Rigorous Case Study? Strategic Management Journal, 29(13): 1465-1474.

Maher, T. (2006). Tourism and hotels in crisis. Ressala print house for publish. Cairo. 21

Mitroff, I. I. (1994). Crisis management and environmentalism: A natural fit. California Management Review, 36(2): 101-113.

Mitroff,F and Anagnos,S,(2001).Hospitality marketing, management journal, 3(4). 12

Niininen,O.,(2013), Five Star Crisis Management - Examples of Best Practice from the Hotel Industry, http://dx.doi.org/10.5772/55209,pp.147-155.

Pearson, Christine M. (2002). A blueprint for crisis management. Ivey Business Journal. January/February: 69-73.

Pforr, C. M. (2006). Hospitality and Politics: Policy, Power and Place. Chichester, UK: Wiley.

Qatawneh, A (2005). Crisis Strategy in Hospitality, management journal, 2(4)12-23.

Ritchie,O, (2004). Crisis Management in Hospitality, hospitality management journal.

Rousaki,B. and Alcott,P.(2007), Exploring the crisis readiness perceptions of hotel managers in the UK, Tourism and Hospitality Research, ,Vol. 7, No. 1, pp. 27-38.

Sabti, S, H. (2002). Crisis Management in Tourism and hospitality. American Press. 24

Scott, W. and Laws, M, (2005). Crisis Management: Challenges and Chances, Journal of Law and Economics, (1)1-4

Septi,P, (2002). Crisis Management Strategies and Destination planning, Journal of Travel Research, 14(5): 2.

Sirafi, H. (2003). Crisis Management. Management Journal, 322.

Spence,A. (1999). The Development of Tourism and hospitality. Management Communication Quarterly, 12

Sturges, David L. (1994). Communicating through crisis: A strategy for organizational survival. Management Communication Quarterly, 7 (3): 297 -

Thelwall.S and Suart, C. (2007). Hospitality Marketing, Management and Marketing Journal, , 191. 
International Journal of Heritage, Tourism and Hospitality Vol. (12), No. (1/2), March, 2018 By: Faculty of Tourism and Hotels, Fayoum University

Tirawi, S. (2008). Crisis management and planning, Tourism Journal. 31

Valackiene.D. (2010). Tourism Destination in Crisis, Tourism Management Journal, 33(2), 99.

Yamamoto.G, Sekeroglu. Ö (2011). Crisis management in the Turkish leather industry.African Journal of Business Management, 5 (8): 3212-3219.

Zhu, Y.(2011).Crisis responses strategies and roles of media in a crisis from a cultural aspect: A case study of San Lu groups melamine crisis in China Mainland. (Unpublished Master Thesis). Ball State University, Indiana. USA, pp. 16-17. 